\title{
Outlining Agents and Policies of Value in the Touristic Economy of the Sacred Valley of Cusco
}

Delineando Agentes e Políticas de Valor na Economia Turística do Vale Sagrado de Cusco

\section{Bruna Pratesi de Oliveira}

\section{(2) OpenEdition}

\section{Journals}

Electronic version

URL: https://journals.openedition.org/aa/9511

DOI: 10.4000/aa.9511

ISSN: 2357-738X

\section{Publisher}

Programa de Pós-Graduação em Antropologia Social (UnB)

Printed version

Number of pages: 228-243

ISSN: 0102-4302

\section{Electronic reference}

Bruna Pratesi de Oliveira, "Outlining Agents and Policies of Value in the Touristic Economy of the

Sacred Valley of Cusco", Anuário Antropológico [Online], v.47 n. 1 | 2022, Online since 31 January 2022, connection on 24 July 2022. URL: http://journals.openedition.org/aa/9511 ; DOI: https://doi.org/ 10.4000/aa.9511

\section{(c) (i) (9)}

Creative Commons - Attribution-NonCommercial-NoDerivatives 4.0 International - CC BY-NC-ND 4.0 https://creativecommons.org/licenses/by-nc-nd/4.0/ 


\section{Outlining Agents and Policies of Value in the Touristic Economy of the Sacred Valley of Cusco}

\section{Bruna Pratesi}

\section{(2) OpenEdition \\ Journals}

\section{Edição electrônica}

URL: http://journals.openedition.org/aa/9511

DOI: $10.4000 / a a .9511$

ISSN: 2357-738X

\section{Editora}

Programa de Pós-Graduação em Antropologia Social (UnB)

\section{Referência eletrônica}

Bruna Pratesi, «Outlining Agents and Policies of Value in the Touristic Economy of the Sacred Valley of Cusco», Anuário Antropológico [Online], v.47 n.1 | 2022. URL: http://journals.openedition.org/aa/9511; DOI: https://doi.org/10.4000/aa.9511

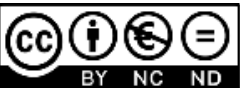

Anuário Antropológico is licensed under a Creative Commons. Atribuição-SemDerivações-SemDerivados CC BY-NC-ND 


\section{Outlining Agents and Policies of Value in the Touristic Economy of the Sacred Valley of Cusco}

DOI: https://doi.org/10.4000/aa.9511

\section{Bruna Pratesi de Oliveira}

University of Brasilia - Brazil

Master's degree in Social Anthropology from the University of Brasilia, Brazil. Researcher at MOBILE (Ethnographic Laboratory of Circulations and Migratory Dynamics) at the Department of Social Anthropology, University of Brasilia.

In this article, I draw from ethnographic and theoretical notes in turn of describing aspects of the tourist market in the Sacred Valley of Cusco, Peru. Guided by Victoria, I address the region's productive chain composed of multiple actors, power arrangements, and vigorous production of difference embedded in historical circumstances. I highlight the actions of Victoria in the community of Accha Alta, the presence of World Vision, and The Centro de Textiles Tradicionales del Cusco as they aggregate value in the processes of coordinating exchanges in the tourism market. In view of this network of touristic production in the Valley's circuit, I raise the questions: are women like Victoria being exploited and victimized by scalability and an oppressive market? Are exogenous projects and cultural transactions under the imperatives of the market the villains of Peruvian and much of Latin American histories? Although there is no easy answer to such massive entanglements, I argue that through in the methodological lens of tourism it is possible to glimpse the extensive and multifaceted commercial chain in the Valley marked by developmental discourses and transnational authorizations.

Development; political economy; Rural and Community Tourism; authenticity
No presente artigo me baseio em notas etnográficas e teóricas para descrever aspectos do mercado turístico no Vale Sagrado de Cusco, Peru. Guiada por Victoria, descrevo a cadeia produtiva da região composta por múltiplos atores, arranjos de poder e uma vigorosa produção da diferença alinhada a circunstâncias históricas. Destaco as ações de Victoria na comunidade de Accha Alta, a presença da World Vision, e o Centro de Textiles Tradicionales del Cusco na medida que estes agregam valores em meio as trocas no mercado turístico. Diante dessa ampla rede de produção turística, proponho as seguintes questões: mulheres como Victória estão sendo exploradas e são vítimas de um mercado opressor? Os projetos exógenos e as transações culturais sob os imperativos do mercado são os vilões da história peruana e outras latino americanas? Embora não haja uma resposta fácil para tais emaranhados, argumento que a partir da ferramenta metodológica do turismo, é possível vislumbrar a extensa e multifacetada cadeia comercial marcada por discursos desenvolvimentistas e autorizações transnacionais.

Desenvolvimento; economia política; Turismo Rural e Comunitário; autenticidade 


\section{Introduction}

During the final months of 2019, I conducted field work in the Sacred Valley of the Incas in Cusco, Peru. I had visited the region a year before and already felt jostled by the rate at which the Valley's worldwide fame as an imagined destination for adventure and mysticism, emerged as a global commodity. Tourism in the Valley made headlines in newspapers, was a theme in government agendas, multinational investments, a means through which people created itineraries, built their communities, and cultivated values for an uncertain future ${ }^{1}$.

As the possibility of doing research in the Valley began to take shape, I was motioned to investigate social life and its political-economic entanglements in the region, mainly those shaped by the tourism industry. The increasingly intentional coordination for capital, propelled by the abundant movement of people, ideas, and values shaped my analytical lens as I drew attention to how people collaborated and were drawn into the touristic market ${ }^{2}$. Tourism shaped my methodological approach as well as ethnographic pathways as I searched for fragments of the underlying values that spoke profoundly of the region's worldly entanglements.

In this article, I describe the tourism market in the Sacred Valley by addressing the region's value chain composed of multiple actors, power arrangements, and vigorous production of difference embedded in historical circumstances. With the methodological and theoretical guidance of Victoria, I propose to outline how she incorporates herself and is incorporated into the market, a process sewn into the material and political presence of World Vision and the textile center in the community of Accha Alta. I describe the presence of the CTTC and how their actions shape touristic values and subjectivities and explore the developmental rhetoric in the region and how it converges in the community tourism model. Finally, I argue that couched in the methodological lens of tourism there is the possibility to glimpse the extensive and multifaceted commercial chain in the Valley that connotes and produces developmental discourses and transnational authorizations.

Such arrangements and relationships were further analyzed by means of qualitative methods, including participant observation, semi-structured interviews, and archival texts from local newspapers and public institutions such as PROMPERÚ, The Ministry of Culture and the Ministry of Foreign Trade and Tourism (MINCETUR). I also carried out extensive bibliographical investigations in the Centro Bartolomé de Las Casas, a private library in Cusco. The project was outlined with an ethnographic approach and a four-month-long fieldwork immersion in the Valley region. The interviews were conducted with a range of economic actors, including tour guides, beneficiaries in tourism, development programs, employees in local NGOs, tourists, and community members involved in local markets.

My main guide and, what anthropologists often call main informant during the time I spent in the Valley, was Victoria Flores. Victoria, a mother of two young girls, lived in the municipality of Calca, in the Sacred Valley and due to kinship obligations, often went to the highland community of Accha Alta, where her mother and extended family lived. On the day we met, Victoria was off to Urubamba, one
1 According to the local newspaper El Sol del CusCo, the region expected to receive 4.79 million tourists in 2019, a 9\% growth compared to the previous year. In the same report, the current Minister of Foreign Trade and Tourism (MINCETUR), Edgar Vásquez, stressed that local authorities would seek to stimulate 19 million soles by 2021 through this "exportación invisible" that didn 't consist of sending and exporting goods, but in promoting visits.

2 This article is a revised version of the second chapter of my dissertation entitled: " $Y$ Ahora Todo el Mundo Viene al Valle": tourism and commodification of difference in the Sacred Valley of Cusco, Peru" (2020). I would like to make a thankful note to those who carefully read and gave insights into this article, particularly participants of the MOBILE group, Laboratory in Ethnography of Mobilities and Migration Dynamics in the Department of Anthropology. Also, a thankful note to my dear supervisor Andrea de Souza Lobo and her methodological considerations and continuing efforts of "ethnographing flows", an intrinsic part of my work. 
of the main towns in the Valley, to meet up with her youngest brother, Adolfo. She told me they had high hopes to promote tourism in their community as they struggled to create means of generating income for their families and community alike.

On this occasion, we sat side-by-side in the colectivo (private van), and Victoria sparked up a conversation with the customary, "where are you from?”. I presented myself and told her I was a researcher from Brazil hoping to learn more about people's lives in the Valley and the effects of tourism. Her eyes lit up as if she'd found the warp and weft of the conversation and started to tell me about her frustrations. She explained her community's inability to benefit economically from tourism, as outsider guides and agencies were the ones profiting: "In truth, in tourism who is profiting more now are the agencies. They are the ones taking the highest part. But, from others. Like Pisac has their ruins, Ollantaytambo has theirs and who is being benefited? The agencies!”.

As her words searched for ways of tackling this dilemma, she emphatically stressed her ongoing desire to have her own business where she could take visitors on tour and showcase the small textile shop in Accha Alta. To start, she wished to have photos taken of the ruins located in her community as a means of marketing her work to attract potential customers. Victoria's brother was studying to become a tourist guide and she had entrepreneurial experience from when she owned her own restaurant and from capacity-building activities with NGOs. These details I would learn throughout our extensive conversations ${ }^{3}$.

Accha Alta was Victoria's birthplace 4 . It was located 20 kilometers from Calca and at an altitude of 4,015 meters above sea level. According to Victoria, the small pueblito had a demography of " 150 men, not counting women, children and widows". The highland town was also the site of the artisanal store and headquarters of The Ancashmarka Association, a women-led group in which Victoria was an active member. The women's association and artisanal center had been sporadically congregating members every month for the last fifteen years to organize the tasks of the associates - in 2019 there were 23 women. The women gathered in the store and sold their products and textiles made both from animal and synthetic yarn. All were handmade, except for decorated alpaca key chains, magnet sculptures of the famous torito de Pucara, cholita dolls, and other products they bought in Cusco and other urban centers.

As Victoria emphasized her business plans, she invited me to visit the ruins and I agreed to assist her in her marketing task by providing photographs. We waited for the rainy weather to clear up and the perfect opportunity to go up to Accha Alta. During our first and other recurring visits, she insisted on the potential of her community of setting in motion services and accommodations similar to the crescent rural and community tourism model in Cusco. As she showed me around the facilities she expressed: "What's the plan? If I bring tourists, I have my store, the bathrooms". She points to smaller house-like structures: "Those are the hotels. That one is a place to eat and the other, a kitchen". Her community tourism prospects, further described in this article, appeared to Victoria as a valuable regional model in which guests had the experience of eating, celebrating, dressing
3 From the start of our relationship my place as an anthropologist was constantly being reaffirmed even though suspicion was a component, and a friendship would soon unfold. Although anthropologists are professionals widely known in Cusco, they are often associated with state representatives that work in museums or archeological sites. However, my touristic presence would be hard to separate from the anthropologist as I resembled the many white "outsider" tourists in the region. I would have a notebook at hand to emphasize my professional position, ask for consent in interviews, and she would express if she didn't want something to be recorded. The discussion on the moral ambiguities of fieldwork deserves careful attention and this article won 't be able to fully display such complexities. 4 Living in the municipality of Calca was strategic in both Victoria's aspirations of providing quality education for her girls as well as furthering her own entrepreneurial business plans. Although such prospects were a reality now, women like Victoria were often obligated to leave their highland communities at a young age and work as maidservants for local patrons in exchange for shelter and schooling. 
in local garments, and sleeping in Andean communities, much like the "Home Away Tourism" allure. Similarly, it proved to be a profitable and community-led touristic arrangement for Accha Alta.

The store brought in very few visitors and the attraction was essentially due to the proximity to the archaeological site of Ancashmarka. The ruins, as Victoria defined, were a set of pre-Incan constructions which were growingly becoming a spot in the tourist circuit of the Sacred Valley. The breathtaking architectonic display along with the touristic complex welcomed the infimum number of customers with parking spots, hotel accommodations, and functional bathrooms, built in the past by World Vision (WV), a North American evangelical Non-Governmental Organization (NGO). According to Victoria, WV's actions in Accha Alta had been completed for more than a decade and the community found itself "abandoned by World Vision". Now, the only more prominent organization working in Accha Alta was the Centro de Textiles Tradicionales del Cusco (CTTC).

As Victoria guided me through Accha Alta and later, other parts of the Valley and the city of Cusco, she theorized about the animosities and competitive aspects amongst associations in her community, the challenging aspects of seeking control in a world of powerful travel agencies, the involvement of social incentives, and most importantly, her aspirations of becoming a protagonist of this narrative as she strived to enter the world of negotiations that came with economic activity and income for her and families alike ${ }^{5}$. As Victoria described her plans and the past and present touristic underpinning in Accha Alta, I inevitably came to question: what kind of market is this? Who are these agencies that penetrate the Valley with highly uncertain promises? By following Victoria's trajectories (Marcus 1995) ${ }^{6}$ and her entangled reality amidst NGOs, public institutions, agencies, and social developmental projects, I drew a sense of intelligibility of the actors that authenticate as well as authorize (Bruner, 2005) the touristic reality in the Valley'.

\section{Touristic projections and the Centro de Textiles Tradicionales del Cusco}

Tourism brought new values and tensions to the community of Accha Alta, both due to the presence of World Vision with its religious permeations and the CTTC's growing expectation to promote activities and a promising scenario for economic progress for both men and women. Victoria's brother was studying to be a tour guide, her sister's husband worked as a porter on the Inca trail in the archaeological park of Machu Picchu, and her mother had already participated, for six years, in textile production activities provided by the Textile Center of Accha Alta.

The Center was a smaller branch of a bigger project led and financed by the Non-Profit Association, Centro de Textiles Tradicionales del Cusco (CTTC). The Center coordinated a textile production project since 1998 in Acchapampa, a sector of Accha Alta, and Victoria's mother had worked in project activities such as weaving and live demonstrations. The production of textile materials was mainly sold in the stores of Cusco and Chinchero, a famous destination in the tourist circuit. Locally, the artisanal community center was built by the association and now
5 I find it important to note that Victoria's desires for money and things come from a place of providing food, transportation, education and enjoyment for her and her daughters. Her "ganas" to have her own money is attached to her ability to cultivate friendships and maintain good relationships with close kin in an economy of care. Although complex, her concerns for others' well-being come from a place of much suffering and emotional and physical distress. Her obligations with her mother -in-law's potatoes harvest were arduous manual labor; working in taxi runs in Calca's bumpy streets also took a toll on her body; leading a restaurant had caused many frictions in her conjugal dynamics. For Victoria, participating in the tourist market meant being able to buy her own textile materials, increase production, and care for others.

6 I highlight what Marcus (1995) defines as "multisided ethnography" to describe the methodological mobilities that shaped my "field" work, situated not only in a wide geographic location, but amidst different social processes and actors. This methodological tool helped me describe the relationships mobilized by Cusco's touristic engagements.

7 In this article, my purpose will not be to unpack the theoretical roadmap of the anthropology of tourism, rather describe political and economic values embedded in the Sacred Valley. However, the inaugural publication of "Hosts and Guests" (Smith 1989 [1978]) stands as a key reference worth mentioning. The work is important as it presented the discipline of anthropology with a nascent theoretical perspective on tourism that sought to analyze case studies, lists issues and problems associated with inequalities, and foremost, addresses the revitalization and transformative qualities present in the interactions between tourists and destination populations. 
housed a meeting place for weaving activities. The CTTC often demanded production from the participants and then sold the items, functioning as a mediator in sales. This particular sector of Accha Alta, unlike Victoria's, enjoyed workshops, had assistance in administrative tasks, and the privileged support from the Center.

The CTTC's main institutional goal is to rescue Cusco's "vanishing” traditional fabrics as well as encourage Andean communities to give continuity to artisanal weaving practices, the use of traditional clothing, and a sense of pride in textile history. Since its foundation, the work provided by the non-profit, which during the time of my research assisted eight communities in Cusco, included projects in education, finance, and workshops aimed at spreading the art of fabric production and ancestral techniques. In an interview with Yolanda at the CTTC office in Cusco, I questioned if there were ever any guided tours provided by the Center and she said they were rare and when they happened it was only for special groups of people: "We work with an NGO in the United States that has a textile tour in Cusco. When they come to see the production of textiles, we organize the visit with the communities". She expressed that, tourists often preferred to visit Chinchero and that the main exchange in Accha Alta wasn't through guided visits, but in buying their textiles to sell in Cusco and even in international events such as the International Folk-Art Market in New Mexico, the United States.

Unlike the marks of abandonment left by World Vision, the CTTC played an important role in Acchapampa. The community was also mentioned as the highest in altitude with which the Center worked, marking a geographical and symbolic distance from urban life, a value portrayed as a continuation of an Inca past idealized in the tourist imagination ${ }^{8}$.

The ancestral character of the art of weaving and the continuities with Incan times were represented in "live" demonstrations in the Center's museums and stores located in different touristic centers in Cusco. The manual technicalities and labor of Andean women and their demonstrations generated an ethos of great value in Cusco's cultural tourism. According to anthropologist Pablo Garcia (2018) and his rich ethnography of political and economic changes in Chinchero, the CTTC continues to be a model enterprise that inspires business enthusiasts to replicate it as a profitable economic regime and cooperative prototype. Today, the shops in Cusco invite visitors to browse the fabric gallery and museums as customers enjoy the famous "live" demonstrations, a dynamic that converges in the imagery of the "living cultures" of Cusco. In that respect, Garcia (2018) signals that contained in the expression of "living cultures" is the interpretation that culture is reduced to folklore and the present is measured in terms of an invented past in danger of being congealed in heritage policies.

Pablo Garcia's (2018) ethnographic findings also showed that the birth of the CTTC occurred at the crossroads between interrelated dimensions such as local and foreign concern for the loss of tradition due to new waves of modernization and the increase in international tourist flows to Cusco, that exploded in the 1990s (Garcia 2018: 168). The porosity between the identity of the Center as an institutionalized organization aligned with the capitalist spirit leads me to add a third
8 The rooted imagination of Incan historical and material culture is further elaborated by authors Pierre L. van den Berghe and Jorge Flores Ochoa (2000) as they define the concept of incanismo.

9 In the book "The Tourism Encounter: refashioning Latin American nations and histories", Florence E. Babb (2011) dedicates a chapter to the discussion of race and gender and the romanticization of rural Andeans in the tourism encounter. 
element: the characteristic of the 1990s and the profile of NGOs in Peru, which, according to the presentation made by Mendoza (2015), required a calculation of market size and economic profitability of prospective projects.

More particularly, the Center originated in 1996 based on the efforts between the Chinchero-born researcher and weaver, Nilda Callañaupa, and foreign anthropologists Cristine and Edward Franquemont, who lived in Chinchero in the 1970s and 1980s. The projects in Accha Alta began in 1998 and until the present, it was common for Victoria to refer to Mrs. Nilda and her influences, especially when she mentioned contact with other countries, the types of special wool that members received, purchased by Nilda, and the publicity of the community promoted by her and the Center.

As Victoria further expressed the makings of her touristic project, Nilda's presence also marked internal disputes and envy in Accha Alta, particularly regarding the use of the complex of Ancashmarka and the discussions around the distribution of sales in the reception of tourists. The different sectors wished to sell their products to customers visiting the complex which, according to Victoria, belonged to her sector. Those linked to the Center demanded the right to occupy the entrance to the site, displaying their products first. Victoria feared that her association's store, a few steps from the entrance, would remain as a second option for tourists. Additionally, given that the members of the Center had access to wool and yarn "sent by Nilda", their products would be sold at a lower price to customers, generating competition:

They will bring their products to sell, and they will create competition. The problem is that the ladies back there, they buy wool at a lower cost. Because Nilda Callañaupa, I don't know from other countries, sends them wool at a lower cost to Acchapampa. So, the associates buy cheaper wool and we buy them at a higher price [...] when a tourist comes, he will see almost the same products, one less and the other more. He will want to buy the one for less because ours is more expensive (Victoria 2019) ${ }^{10}$.

As a result, Nilda's presence acquired considerable influence in the configuration of social and political relations within Cusco's communities. Certainly, the community of Accha Alta received an exceptionally small number of tourists and travel agencies had less interest in promoting this space compared to the famous centers in Chinchero. Therefore, Garcia's ethnography (2018) leads us to reflect upon how the advent of tourism required the reconfiguration of space and growing management among the internal arrangements of communities such as Victoria's. In this scenario, segmentations were presented in ways that some members enjoyed unequal opportunities creating discrimination and internal animosities.

Centers like the ones in Chinchero and Accha Alta marked touristic contact spaces where authenticity was negotiated and authorized in the face of the CTTC's presence. The category of authenticity, widely discussed in the anthropological literature on tourism, is understood in this essay in relation to anthropologist Ed-
10 Van a traer sus prendas e van criar competencia. El problema es que las señoras de allá compran lana con menos costo. Por qué Nilda Callañaupa, no sé de otro país, envíales lana con costo menor. A Acchapampa. Entonces los miembros compran lana a menor precio y nosotros compramos a mayor precio. [...] um turista cuando viene, vá ver casi igual, el otro menos y el otro más. Vas a querer comprar el uno por menos porque el nuestro es más caro (Victoria, 2019). 
ward Bruner (2005). The author agrees with Arjun Appadurai (1986), that authenticity is increasingly becoming a connoisseurship policy, the economic policy of taste, status, and discrimination and attests that authenticity is an issue of power and who has the right to authorize it (Bruner, 2005: 163). Bruner (2005) prefers the term authority over essentialist vocabulary because it changes the nature of the discussion and incorporates the agency of the actors: "No longer is authenticity a property inherent in an object, forever fixed in time; instead, it is a social process, a struggle in which competing interests argue for their own interpretations of history." (Bruner, 2005: 163).

The demand for a traditional identity, rooted in Cusco, permeated the valorization of customs, ethnic qualities, and a rural way of life. The expectations generated by World Vision, further discussed, also contributed to the reproduction of the complexities of rural societies. On the potential outcomes of the profitable textile centers like the ones in Chinchero, Garcia (2018) argues that:

NGOs had given them an internal organization, as well as a timeframe and ideological framework that made these centers appear and function more like a museum or theme park than other things. This process of museification of the textile practice, just like the one that affected the historic center, had converted the centers into spaces that could be easily co-opted, packaged, and sold by the tourist industry. The discourse of living cultures masked a reality significantly at odds with the principles it claimed to serve (Garcia 2018, 223, author's own translation) ${ }^{11}$.

In that sense, based on Garcia's (2018) contributions, the community of Accha Alta, its textile center, and the archaeological complex of Ancashmarka, would be in danger of increasingly leaning towards a theme park model ready to be sold and packaged by tourism. In addition, the center could easily fall into the hands of advertisement largely propelled by not only agencies such as NGOs and organizations like the CTTC, but by local authorities such as the Ministry of Culture, the public agency responsible for overseeing the site. Simultaneously, entrepreneurial subjectivities and local groups flourished under the external impulses of NGOs, conferring ongoing inequalities. Such projections confirmed much of Victoria's criticism and fears towards the ongoing interest in Accha Alta.

In relation to the museification process described by Garcia (2018), Chinchero's textile centers suffered excessive exploitation from the tourist dynamics, such as the creation of guided tours, packages, and stores with ethnic requirements and symbols of otherness, desirable assets in the touristic experience. In Chinchero, it was common for a textile center to be intentionally represented as the space of the home and the domain of the intimate and "real life" and the women protagonists in these demonstrations. Women danced, sang, and manipulated materials used in fabric making, such as dyes, pots, wool, and textile tools to fulfill the objectives of sensitizing and convincing tourists to, at the end of the tour, buy their products. After the demonstrations, handling and especially dressing tourists in Andean
11 Las ONG les habían dado una organización interna, así como un marco temporal e ideológico que hacía que estos centros aparecieran y funcionaran más como museos o parques temáticos que otra cosa. Este proceso de museificación de la prática textile, al igual que el que afectaba al centro histórico, había covertido a los centros en espacios que podían ser fácilmente cooptados, empaquetados y vendidos por la industria turística. El discurso de la cultura viva enmascaraba una realidad significativamente reñida con los principios que declaraba servir (Garcia 2018, 223). 
clothes, ponchos and hats market the height of sentimental interaction, providing smiles and many photographs.

In such events and much of the touristic imagination in Cusco, the gendered figure of the Andean woman stood out in "traditional" representations, accompanied by vibrant colored garments, and was always announced in association with distant and "remote" communities. The rural and community tourist destination of the Valley was associated to a place of curiosity, imagination, and exoticism and its forms of life, in which the distant highland and Quechua-speaking communities and the Andean woman, stood out as the main signifiers of "traditional" culture ${ }^{12}$.

This digression further complexifies Victoria's role as an Andean woman, part of the tourism market. When she wasn't undertaking arduous manual labor demanded by her families' lands in her community, she spent her days weaving and finding means to make this practice a source of income for her and her daughters. She was constantly seeking to bring new resources to the women's Association, in which only she spoke Spanish - others only spoke Quechua - and could communicate with customers. Weaving was an essentially feminine activity for Victoria and, according to her, her role as a woman was to weave, dye, sell, and master the process of textile making, including the materials and different types of wool in fabric production.

This leads me to relate Victoria's touristic prospects and her expressed role as a woman within simultaneous obligations in the production of Andean textiles and her identity. Such underpinnings lead me to rescue what anthropologists John and Jean Comaroff (2009) emphasize about the critical measures and tactical awareness of those who claim their ethnic "nature" through the foundations of "ethno-preneurialism". Victoria's emphasis on the production of textiles takes place amidst the culture of the region's tourist market combined with a desire for agency in the world as to make the abstraction of identity concrete. According to the authors, changes from the production of material to immaterial value, such as the marketing of experiences and means of self-production, signals the presence of domains of existence that once escaped the market. In this perspective, the market exceeds the mere sale of goods and services, and now, more than ever involves the cultivation of emotional, cognitive, and lifestyle attachments made by choice. In this process, textile confectioning in Victoria's practice can be perceived as a way in which cultural affiliations solidify into a rich and effective ethnic awareness:

It is that commodity exchange and the stuff of difference are inflecting each other, with growing intensity: just as culture is being commodified, so the commodity is being explicitly cultural - and, consequently, is increasingly apprehended as the generic source of sociality (Comaroff and Comaroff 2009, 28).

Based on the reflections above, it is possible to think of Victoria's textile-making aligned with her pulsating identity as an Andean woman given that her individuality, affections, and self-production are made in the expression of her
12 Florence E. Babb (2010) argues that in Andean Peru "tourism has a gendered and racialized effect, as romanticized or exoticized images are used - by the state and indigenous people - to entice travelers, who expect to find cultural difference prominently on display" (Babb 2010, 154). This idea speaks to the traditional imagination in much of Cusco's touristic encounters. 
entrepreneurship in the market and in the identity economy, by which human subjects cultural objects, produce, reproduce and modify each other (Comaroff; Comaroff 2009). Hence, Victoria is both a producer and a consumer of her own preferences and subjectivity and it is through the circulation of cultural products and products of experience that the collective dimension of textile confection is reinforced, both in the market and lifeways. Nevertheless, it is important to note that this subjective movement communicates a dynamic under constant pressure (Povinelli 2001) as the subjects are encouraged to maneuver in a field of powerful contrasting logics.

As we focus once again on the ongoing profit-driven encounters in Accha Alta, the dynamics in Chinchero echoed Victoria's concerns as it fell more and more into the hands of travel agencies and outside tour guides. As I tried to comprehend her criticism more thoroughly, I understood that the theme park process, based on the implications described by Chinchero's textile centers, was related not to it becoming more or less real but being organized by new authorizations on what is and isn't authentic as well as recognizable by the tourist gaze ${ }^{13}$. It is important to note that such characteristics did not, to an extent, directly describe the dynamics in Accha Alta, since the community had not consolidated frequent demonstrations nor attracted an effective and highly publicized interest from travel agencies. However, it is important to consider that as the availability for capital grew, political confluences and new ambiguous and asymmetric transactions grew concomitantly.

In this scenario, the production of authority is marketed by collaborations that are linked to a common cause or phenomenon and processual arrangements. In the Valley, NGOs, associations, and communities seek strategies in cooperation while marking cultural practices, traditions, and customs as they are producers of difference. Although, the theme park and commercial activity on the premise of community life is a risk in the advent of Chinchero's history, in Accha Alta, "authentic" values in the tourism market are expressed through economic accomplishments and potentialities embedded in developmental ideals of progress.

Victoria's projects and projections echoed such ideals. Complementary to her daily activities, Victoria's perception of tourism as a commercial activity with a potential for community progress, illustrated strong expectations regarding the prospective benefits of economic activities in Accha Alta. With the advent of tourism in Victoria's community, cultural practices became a powerful means to occupy an active place in the market and in that effect, different actors celebrated rescuing vanishing practices while aligning this discourse with economic development and social transformation. To further discuss the categories tied into the production of difference and developmental ideals, encountered by the community, I analyze the presence of World Vision, another foundational authority in Accha Alta's incipient yet emergent touristic market.
13 Please refer to sociologist John Urry (2002) for a more detailed analysis of the concept. 


\section{Between social visions and community development}

The space around the ruins of Ancashmarka was composed of material features aligned with the presence of World Vision's (WV) projects that, as expressed by Victoria, had propelled exchanges and interactions with visitors in the past and now stood as a potential source of insertion in tourism. As I looked further into WV's presence in the community, I tried to comprehend the effects of the NGO in the community and further investigate the mediation of these material constructions left abandoned by the effects of time. On such premise, I looked particularly towards their political and economic underpinnings. By questioning the political dimensions in the production of value, I brought attention to their ascension as prominent figures in international exchanges. I commence by focusing on the research of social scientist Julián Gualli (2005) and his writings on WV and its international proposal of action.

Gualli (2005) describes the actions of the NGO in its assistentialist and proselytizing dimensions beginning in the 1980s and 1990s in the Ecuadorian indigenous sector and points to its founder, a North American evangelical preacher. Amidst the cold war, the North American-based ideology of WV is centered on the belief that its country would have God's purpose to guide the rest of the world towards progress and freedom. Such a mission established a slippery notion of racial superiority in relation to its "younger brother" - in the "underdeveloped" world - and propelled a moral order to civilize him (Gualli 2005, 18). Furthermore, this fundamentalist civilizing sense would be reformulated in the 1990s based on a commitment to "social responsibility" aligned with a neo-evangelizing mission. In Ecuador, the target beneficiaries of the organization were indigenous communities, and its latent assistance proposal was based on a "transformative development" and social ascension of poor populations. The operation in Peru took place during the same period, precisely in 1994, and currently, the organization works with more than 500 communities across the country, including the region of Cusco.

According to Gualli (2005), in recent years the multinational NGO had as its main focus the establishment of a model of justice for impoverished populations in marginal conditions and was funded by both the public and private sector. Such funds benefited assistance and welfare projects aimed at children and their families and were based on education, vocational training, agricultural development, health programs, and income-generating incentives. Ultimately, impoverished highland rural communities were the beneficiaries of the organization's transformational missions and much of the Sacred Valley was targeted on such premises (Carreño 2010).

The elimination of poverty was conceived within the vision of justice for campesino and indigenous communities ${ }^{14}$, especially actions that remedied, according to the NGO, the lack of power and their inability to organize themselves and make political decisions in communities. Anthropologist Guillermo Carreño (2010), when developing an ethnography on communal conflicts and the evangelical presence in Cusco, describes how the evangelizing discourse of redemption of
14 "Campesino" and "Indigenous" will not be analyzed in-depth in this article. However, it is important to note that such categories are dynamic, contextual, and highly politically charged categories in Peru and many Latin American countries. 
the population constituted a source of liberation from stereotypical associations to "Highland Indians" 15 . Simultaneously, the author states that "the evangelical discourse does not challenge but reinforce ideologies of social differentiation in which the culturally indigenous campesino is essentially associated with ignorance and poverty" (Carreño 2010: 667) ${ }^{16}$.

What I came across in Accha Alta made me reflect upon the recurring aspects of the tourism market in Cusco, which included a social-based developmental rhetoric directed at highland impoverished communities. The region's widely disseminated pro-poor tourism, a transnational initiative, was celebrated as a replicable community-based model at the same time that tourism became a synonym for progress guided by neoliberal forces (Fuller 2008). In the Sacred Valley, community tourism became a tool for the eradication of poverty and unemployment, and for economists and specialists, it represented an engine for the sustainable development of Cusco (Casas et al. 2012), generating enormous expectations in rural populations not only in Cusco, but throughout Latin America.

In recent years in Peru, the emergence of network alliances between NGOs and their promotional and facilitating projects has made the country an active proponent in raising funds for international cooperation. As presented by Galán (2012), Rural and Community Tourism (RCT) is a tool for cooperation and a global trend that focuses on sustainable and inclusive tourism as a tool for development. The community-based model is defined as a strategy of communal organization that institutionally considers the role of touristic development through "agricultural, cultural and environmental heritage" (Gascón; Cañada 2005). Such plans were conceived based on the interests of countries part of the Organization for Economic Cooperation and Development, the World Bank, and the United Nations. In fact, a pro-poor methodology and project were implemented in 2003 as an initiative of the World Tourism Organization.

Based on such activities that echo a "pro-poor" rhetoric, the intersection between religious and transnational actors mentioned above highlight the developmental strategies on the part of the international order, which again comes into play in the civilizing project of the State (and the Church) and incorporates the formula for the elimination of poverty. This baseline, however, is aligned with the objectification of the cultural value of difference and is based on a transformative developmental strategy. It is from this touristic engagement that I point to the ideological panorama and practical commitment of actions within community development as one of the main pillars of Rural and Community Tourism.

The problematization of the category of poverty and discourses in recognition of its threatening condition to "modernity" was highlighted by anthropologist Arturo Escobar (1995). According to Escobar (1995), the global emphasis on the phenomenon of poverty, in the modern sense, arose only in view of the spread of the market economy and the consequent tearing of community ties that deprived millions of people of access to land and natural resources. In this scenario, impoverished populations needed to be assisted and the problem of poverty and pauperism attacked, as it was aligned with undesirable attitudes such as: "[...]
15 Such analysis made me reflect upon Victoria's definition of her community as indigenous and not campesino, and highlights important historical outlines of such complex categories. In the midst of the Peruvian state's land reform project, the Peruvian military government eliminated the terms "indians" and "indigenous" from official documents and replaced them with the term "campesino" in order to eliminate the "problem" of races from politics (Baud et al., 2006). It also hoped to create cooperative and corporate companies to produce workers part of the insurgent national project. 16 "El discurso evangélico no reta, sino más bien refuerza, ideologías de diferenciación social en las cuales lo campesino culturalmente indígena está asociado esencialmente a la ignorancia y la pobreza". Carreño (2012) also highlights the evangelical church's growing interests in cultivating indigenous religiosity as a means of benefitting from the growing tourism market in the region of Cusco. Practices once condemned are now expected to generate income, new imaginaries for development and progress, and a higher number of evangelical adherents. 
mobility, vagrancy, independence, frugality, promiscuity, ignorance, and refusal to accept social duties, to work, and to submit to the logic of expansion of "needs" (Escobar 1995: 23). State policies sought out to act and propose action plans in the "social" sphere and intervene in education, health, hygiene, and other practices, transforming the poor into objects of knowledge and administration for the world order.

The parameters of measuring poverty at the global level were translated into economic conceptions, in which in a market society, the poor defined themselves as devoid of wealth compared to the rich nation-states, also creating the division between "developed" and "underdeveloped". Improvement and social reforms needed to be carried out to tackle the "problem of poverty" and thus the salvation of development and its technological, scientific, planning, and international organizational tools emerged as a formula to bring salvation to the poorest countries, including Peru.

It is in this historical process, widely discussed by the author, that I identify the favorable conditions for the presence of messianic organizations such as WV in the highland communities in Peru, which in addition to a missionary-Christian base is sustained in the ideological discourse of salvation in light of reforms and "social transformations". Such notions are attached to the underpinning of tourism in Accha Alta as they resonate with much of the compelling developmental notions and projects in poor campesino and indigenous communities. In addition, the premise of cultural tourism in Accha Alta further complexifies the discussion.

On the particularity of indigenous communities and the growing concern with new markets, John and Jean Comaroff (2009), emphasize that in the midst of the era of empires, there was an increase in the production of sociological knowledge and anthropological "science" that served in the reification and valorization of cultural difference. Furthermore, the affirmation of the resilience of difference served as a justification for colonial domination under the distinction of the "other" ${ }^{17}$. According to the authors, as decolonization gained strength, the demands for sovereignty and civil rights were intensified by the old international order that brought the "problem" of difference to the public sphere. Thereby, what stands out in the world momentum are the markers of difference which have become desirable and scarce commodities as a result of the increasing heterogeneity of nation-states that feed on the implosion of identity policies.

As explained by John and Jean Comaroff (2009), much of the modern political imagination aspires to Eurocentric conquests, whereby governability is always a mutual concession in the presence of "others" who threaten civic unity and therefore, need to be confined to the "private", surrounded in their homes, congregations, associations, and communities (idem, 46). Furthermore, the impacts of neoliberalism help to give value to place while placing it in a political field beyond itself, establishing standards of practical needs with ethical principles capable of encompassing religious and cultural diversity amid the civil order of "universal" citizenship (idem, 48). The mission of NGOs continues to exercise their role in these historical circumstances, and insofar as ethnicity is chosen as a principle of
17 Discussion broadly delineated by the anthropologist Talal Asad (1973). 
recognition in the common language of international transactions, the ontology of identity ensures the common basis of political engagements.

The presence of NGOs such as WV in Accha Alta appeared in the face of this panorama that was based on the simultaneous movement of recognizing indigenous identity under the logic of assistance and solidarity in the face of poverty policies and organizational actions as an efficient agent in consolidating the ideal of social development. At the same time, the logic of funding through international donations, in light of financing developmental projects, inserted its performance in market transactions with a productive and economic focus beyond proselytizing.

Henceforth, community development is born in this paradoxical terrain of economic orientation and articulations of cultural difference in the transnational context that implies making the region of Cusco and its vast rural regions a site of tourism development. The duality is built upon the macro-political agenda of rich countries, organized in favor of economic growth to the same extent that marginalized and impoverished populations are the beneficiaries of such agencies through training projects with specific rules and values. Ultimately, aspirations for Rural and Community Tourism in Accha Alta, a growing value in the region, is born in the vicissitudes of community development, whose operation takes place in an emerging worldly and cultural process linked to local business and enterprise, unequal encounters, and new arrangements of power and culture (Tsing 2005).

\section{Final outlines}

It is at this moment that we ask: are women, like Victoria, being exploited and victimized by scalability and an oppressive market? Are exogenous projects and cultural transactions under the imperatives of the market the villains of Peruvian and much of Latin American histories? And what are the long-term effects of a future based on ethnic entrepreneurship with the support of agents with their intentions and interests? Such questions do not have an easy answer, nor a certain prospect, nonetheless what became evident was the fact that for Victoria, tourism enterprise in the Valley presented itself as a possibility and a means of living, a job that she mastered its codes and, faced with a feeling of both hope and despair, propelled her plans of working in tourism as a means of prosperity for her and her family.

As Comaroff and Comaroff (2009) conclude, the economy of identity, a fertile space for tourism, feeds on profound ambivalences in modern life: "a feeling of exile from 'authentic' being that seeks to requite itself in encounters with 'authentic' otherness - albeit in a consumable form" (idem, 140). I agree, with the authors, that it is not a matter of praising the unstable and dialectical movement of incorporating identity in the commodification of difference under the logic of the market, but of explaining its silent erosion of the politicization principles that carry a set of costs and contradictions. The question of who benefits and who is 
afflicted in a tourism model that has as its raison d'être a colonial and ostensive nostalgic imagery and whose reproduction is made in the aspirations of development, in my reading has a strong potential to co-opt with and accentuate the cleavages (class, race, and gender) and the expressive demand for exoticism.

As the official narrative of reality is in the hands of development and multilateral models, its creative potential feeds on the erosion of Victoria's hopes for autonomy and prosperity in her community and association. The present alarmist tone cannot be confused with the lack of capacity of the members of Accha Alta and other centers, to rebuild themselves and carry out actions and aspirations for sovereignty as worldly demands and urgencies. Victoria's criticism is precisely her exclusion from development processes and how a tourist model in her community does not fit in her understanding, without her control, without being managed by the population and, finally, that is benefitting and enriching outsiders such as guides, agencies, and foreign centers. Perhaps greater independence within a diversified economy is a possible future, but as the abandonment of World Vision shows, and the constant obligations to the CTTC show, the negligent and usurpation potential of tourist agents is a persistent factor.

Ultimately, I tend to agree that tourism projects and prospects, immersed in ethnic markets, their fortunes, and those that depend on them, often fall into the geographical dynamics of political instability (Comaroff and Comaroff 2009). What is relative is the prospection of difference, whose measure is in relation to the mainstream and developmental and measured by the colonial desire to transcend difference and perpetuate the nostalgic impossibility of seeing, feeling, and experiencing otherness. Finally, based on Victoria's trajectory in the Valley's economic desires, it is possible to glimpse the extensive and multifaceted commercial chain marked by developmental discourses, persistent production of otherness, and transnational authorizations.

Such findings in Accha Alta can also lead us to further reflect upon utilizing developmental projections, such as the flows of tourism, as methodological tools to better describe capital, scales, place as well as situated and worldly entanglements. How can contextual and political circumstances in various regions of Peru and other Latin American countries help outline shifts in economic actors, values, and trends? That is a question we as anthropologists can continue to pursue and although there is no easy answer to such massive entanglements, looking at how people are incorporated and incorporate themselves into the flows of goods, values and capital can continue to be a possible and effective methodological tool for anthropological research. 


\section{References}

Appadurai, Arjun. 1986. The social life of things: commodities in cultural perspective. Cambridge, UK: Cambridge University Press.

Babb, Florence E. 2010. The tourism encounter: fashioning Latin American nations and histories. Stanford, CA: Stanford California Press.

Baud, Michiel et al. 2006. "Introducción: el turismo como una estrategia para el desarrollo sostenible". In Turismo y desarrollo sostenible en Perú y Bolivia, org. Annelou Ypeij, e Annelies Zoomers. Quito: Abya Yala.

Bruner, Edward. 2005. Culture on Tour: ethnographies of travel. Chicago: University of Chicago Press.

Casas, Amalia Cristina, Amparo Soler Domingo, e Vicente Jaime Pastor. 2012. "El turismo comunitario como instrumento de erradicación de la pobreza: potencialidades para su desarrollo en Cuzco (Perú)". In Cuadernos de Turismo 30: 91-108.

Carreño, Guilhermo. 2010. "Conversiones religiosas y conflictos comunales. Las iglesias evangélicas y la creciente importancia del turismo em comunidades campesinas del Cusco". In Perú: El problema agrario en debate. Seminario Permanente de Investigación Agraria - SEPIA XIII, 644-80, eds. Patricia Ames, y Víctor Caballero. Lima: SEPIA.

Comaroff, John; Comaroff, Jean. 2009. Ethnicity, Inc. Chicago: University of Chicago Press.

Escobar, Arturo. 1995. Encountering Development: the making and unmaking of the third world. New Jersey: Princeton University Press.

Galán, Beatriz Pérez. 2012. "Retoricas de turismo y desarrollo en Los Andes: la red de turismo rural comunitario Pacha Paqareq, Perú”. In ¿El turismo es cosa de pobres? Patrimonio cultural, pueblos indígenas y nuevas formas de turismo em América Latina, eds. Raúl H. Asensio, y Beatriz Pérez Galán, 171-200. Lima: Pasos; Instituto de Estudios Peruanos.

Garcia, Pablo. 2018. En el nombre del turista: paisaje, patrimonio y cambio social em Chinchero. Lima: Institutos de Estudios Peruanos.

Gascón, Jordi, e Ernest Cañada. 2005. Viajar a todo tren: turismo, desarrollo y sostenibilidad. Barcelona: Icaria.

Gualli, G. Julian. 2005. "Visión Mundial en el ámbito del desarrollo local”. In Experiencias en gestión y desarrollo local. Quito: Ciudad, Centro de Investigaciones EED/EZE, Universidad Andina Simón Bolívar.

Fuller, Norma. 2009. Turismo y cultura: entre el entusiasmo y el recelo. Lima: Fondo Editorial de la Pontificia Universidad Católica del Perú.

Marcus, George. 1995. Ethnography in/of the world system: the emergence of multi-sited ethnography. Annual Review of Anthropology 24:.95-117.

Mendoza, Ivan. 2015. Desarrollo rural y ONGs en el Perú (1980-2015): algunos puntos críticos y desafíos. Palestra para El Seminario Internacional sobre Desarrollo Rural en la Región Andina y Amazónica. Peru: Desco.

Povinelli, Elizabeth. 2001. Consuming geist: popontology and the spirit of capital in Indigenous Australia. In Millennial Capitalism and the Culture of Neoliberalism, ed. John Comaroff, and Jean Comaroff, 241-70. London: Duke University Press.

Smith, Valene, ed. 1989. Hosts and guests: the anthropology of tourism second edition. Philadelphia: University of Pennsylvania Press.

Talal, Asad. 1973. Anthropology and the Colonial Encounter. London: Ithaca Press.

Tsing, Anna L. 2005. Friction: an ethnography of global connection. New Jersey: Prince- 
Bruna Pratesi

ton University Press.

Urry, John. 2002. The tourist gaze, 2nd. ed. London: Sage.

van den Berghe, Pierre L. and Jorge Flores Ochoa. 2000. Tourism and nativistic ideology in Cuzco, Peru. Annals of Tourism Research 27(1): 7-26. 